\title{
Qazi Nazrul Islam For Women's Emancipation
}

\author{
Mohammad Abu Tayyub Khan \\ Department of Bengali \\ University of Karachi
}

\begin{abstract}
Poet Qazi Nazrul Islam, as a poet always commanded a highly privileged position amongst the youth of Bengal in pre-partition India. The emergence of the women's movement throughout the world, the work of the United Nations on women's issues has an emancipation of over half of humankind from the oppression in which they have lived for centuries for over two millenniums. Although the United Nations has not succeeded in its goals, the very prospect of effecting such emancipation carries with it the promise of bringing the greatest revolution in human history.

The end of World War II, witnessed the global community, recognizing the importance of women's right. Those attempts of recognition, due in part to the pressures that women had begun to put on their own governments, helped to force issues on women's concerns for the global agenda. By 1995, four world conferences of the United Nations, on women and their right of equality with men (the 1975 conference in Mexico City. Mexico; the 1980 conference in Copenhagen, Denmark, the 1985 conference in Nairobi, Kenya; and the conference in Beijing, China and in 1979 international convention, the Convention on the Elimination of all forms of Discrimination Against Women).

Qazi Nazrul Islam, long before the United Nations was created, talked about the issues that sought promoted equality for women. These issues, unlike those of the United Nations and some in the women's movement, sought equality for women in the broader context of a total cultural change in the new world. So, one finds him advocating (on behalf of women) the political, economic, and social rights, which are generally associated with human rights regime, we must look beyond such a finding to the cultural focus of his poetic outpourings.
\end{abstract}

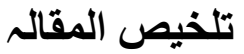

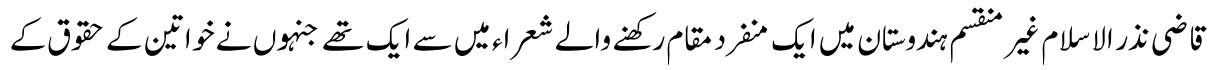

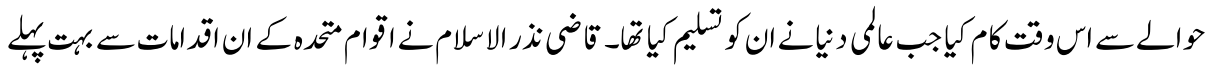

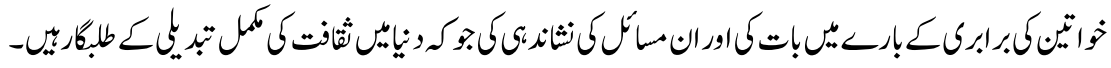

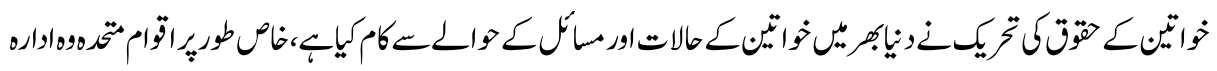

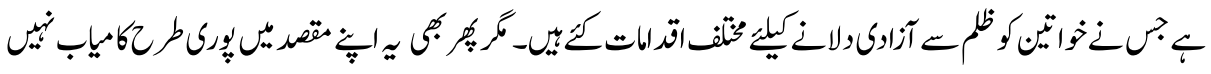

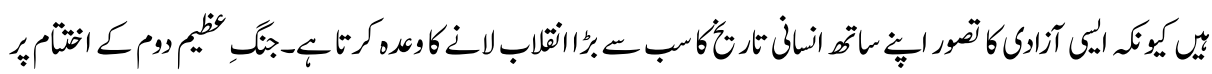

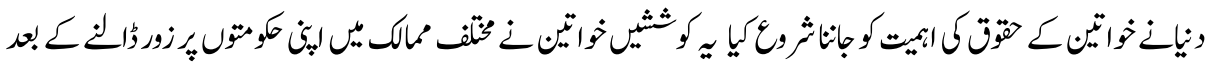

$$
\begin{aligned}
& \text { منوائي كـ عائى سمحير }
\end{aligned}
$$




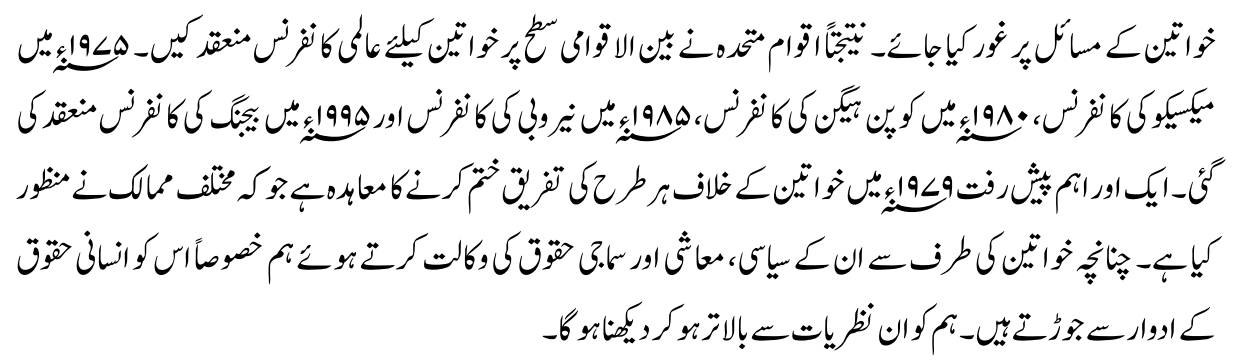

\section{Women's Emancipation}

Qazi Nazrul Islam challenged us to review our history. In that review, he informed us, that there is no difference between men and women. Whatever the human grief, pain, or evil we can properly attribute to human agency, an accurate assessment evil will disclose that men and women share equal responsibility for these. If we were to do likewise in ascertaining the cause of "great or benevolent achievements"(Langley,2007) ${ }^{1}$ throughout the world, we will again discover that the credit is shared by both men and women.

Second, Nazrul Islam challenged the fundamental belief, known as the Abrahamic religions-Islam, Judaism, and Christianity. Their belief is that women compelled men to convict sinful act.

I sing of Equality -

In my eye there's no difference between

man and woman. Man is responsible

for half of the great, noble, ever-lasting

things of the world, and the other half

goes to the credit of women. Again

for half of the sin, sorrow, grief

and tears of human life man is

responsible, while the other half is

wrought by woman

who is he that hates woman as a veritable Hell?

tell him, the original sin is no woman (Huda, 2000). ${ }^{2}$

(Nazrul)

Nazrul was more interested in uprooting the structure of what some scholars call the "figured world" that "socially and culturally constructed realm of interpretations in which particular characters and actors are recognized, significance is assigned to certain acts, and particular outcomes are valued over other" (Holland, 1998). It is this "figured world" that interacts with (and often out of which we have) the world of narratives; it is also the world which gives rise to certain "core values" and belief systems. 
While challenging the system of beliefs and its underlying narrative, Nazrul hoped desire to discredit the belief and its associated narrative, and with an optimistic approach to create a new "figured world" in which women's contribution are recognized and the outcomes of their actions will be assigned proper values. Hence, his idea is expressed in the third line which emphases the construction of the new "figured world".

Every great victory, every great adventure

has been ennobled by sacrifices

made by mothers, sisters and wives.

History records the names of men

who have been killed in wars,

but not the women who have been widowed.

Does anybody inscribe on a hero's monument

all the mothers who sacrificed their hearts,

all the sisters who offered their services?

Never in history has man's sword

earned victory all by itself.

inspiration and strength

have come from the goddess of victory-a woman! (Huda, 2000) ${ }^{3}$

(Nazrul)

Nazrul focuses here, women's part of the "figured world", men have created to ensure changes in history and culture by recognizing the activities of women as mothers, sisters and wives. What would be the fate of war, if mothers who "sacrifice their hearts" were placed on the same pedestal, accorded the same honour, and given the same social access by virtue of her heroic standing? They would become a source of social and moral refinement that would undermine and subvert many wars. The "sacrifice" of the heart must not be generally known, except in the privacy of the victim's own company or family or in the occasional search for public support, which politicians often shamelessly seek. Even the great tragedians of literary history, when they have touched on the area of "sacrifice", have sought to do so more to invoke pity than to seek a degree of equality for women, not to mention creating a new "figured world."

A fourth theme in Nazrul's position on women is their "humanizing" and "softening" influence on men, children and human society as a whole. To him, men-in general are harsh, often heartless and lacks affection. Women on the other hand generally posses loving, caring, affectionate attributes. And in their offering of these attributes to society, women neutralize some of the effects of men's psychic and spiritual constitution. More important, they often create a setting out of which that constitution might be transcended.

Nazrul has given attention to history, belief systems, figured universes, and certain assumed attributes of the psychic and spiritual constitution of men and women. He 
turned to some specific socio-cultural and commercial practices that, according to him, imprisoned women. And he could not be more insightful in his focus on these practices, because they are in the writer's judgment, among the most powerful sources of the inequality in which women are still obliged to live and survive.

Nazrul felt that women would have to make effort to change their status in the society and to achieve their rights and to remove the "security blanket" which men enjoyed that women are dependent on them. In short, the emancipation of women from the traditional and socio-cultural practices has implications for men, in helping the latter to see their own dependence on women.

Nazrul was more radical for women and for the society, within which emancipation exists as earlier indicated, as part of the new society he was seeking to create; and he used the limitations within which the socio-cultural and the communal practices had confined women to construct the image of slavery and imprisonment. In his own words:

Tell me, woman, which tyrant

put you in this prison-palace

of gold and silver ornaments?

You don't show eagerness to express yourself, cowardly you murmur behind the screen.

You can't look straight into one's eyes

You've bangles on your wrists, anklets around you feet.

Tear open you, veil, woman, break your chains into pieces!

Cast away the veil that turned you into a coward!

Get rid of all your marks of slavery,

all you ornaments! (Huda, 2000)

(Nazrul)

Wearing bangles and other ornaments are a form of aesthetic expression in which many women are engaged. But Nazrul felt that these forms of aesthetic expression were not of women's making or choosing; they were, in his view, form the socially and culturally dominant world of men, who prescribed the veil and dictated how women should dress, how they should feel, and how they should be. The tyranny, the prisons, and the slavery of these practices should be overthrown.

To cultural feminists, who view the women's movements as offering an alternative to the model of the society developed by men, not of providing ways to "fit into" the alreadydesigned cultural system men have created, Nazrul's stand is praiseworthy. But he goes beyond the position of the cultural feminist because he sees women as having occupied a 
social and spiritual world that was not only stifling, but one that was an "underground of death" - civil and cultural death, one that killed the full expression of what women could and should be and by extension, what society could and should be (Since women, to him, were a numerical half of human society, it followed that the so-called modern society itself was at least partially dead).

The emancipation of women for him was therefore, the means by which humankind will finally find its own emancipation. So he called on women to recognize that the male god of death must die; that if this god must die-and it must, if spiritual humankind is to be fully born - then women must be prepared to serve poison where they formerly served nectar; and that part of this poison is the trampling the (symbolized by their "broken bangles") the male god of death along with his sovereign crown, his figured world. Nazrul ended his poem "woman" in an hopeful mode:

That day is not far off

when the world shall sing the glory of woman

along with that of man! (Huda, 2000) ${ }^{5}$

Since the development about which Nazrul spoke and gave his support is a condition of society that would be intolerant of social as well as gender inequality, the reader can readily appreciate why for him, the emancipation for women is central to the development of societies? True, it might be argued that the emancipation of women does not have to precede, sequentially, the development of societies (and Nazrul is not making that claim, as some might suggest). That emancipation must, however, be interactive and coeval with development.

Like Gandhi, Martha Nussbaum, and Frantz Fanon, to mention a few thinkers, Nazrul was of the view that one group of persons cannot effect the development of another group. People must be in control of the content, trajectory, and process of the change they seek. Left to men alone, development will never come to represent the revolution in human consciousness he sought to sponsor. Without that revolutionary change, the continuation of the old ways in the male-made cultural prisons, and in the maleconstructed "underground of death" (Langley, 2007) ${ }^{6}$ will be assured. Women and other oppressed groups such as peasants, but especially women, must become lead agents in national and international development.

One could say, at this juncture, that while Nazrul was far ahead of his times, his thinking that women should be the authors of their own development is not unique.

The genius of Nazrul shines again when he unites not only the Bengalis, but also the people of Pakistan and India including the Christians against injustice. If he wants to speak to all people, he does not resort to esoteric poetic references - he uses traditions 
that can be understood by the largest population. In a poem entitled "Prostitute," Nazrul addresses the problems not only of these women but also of their children:

\section{Prostitute}

Who calls you a prostitute, Mother?

Who spits at you?

Perhaps you were suckled by someone

As chaste as Seeta.

You may not be chaste,

Yet you are one of the family

Of all our mothers and sisters.

Your sons are like any of us [sic] sons,

As capable of achieving fame and honor

As any of us, capable of entering heaving (Huda, 2000). ${ }^{7}$

In this poem, he referred to not only the heroes and heroines of the epics, but the Hindu gods and the Christian's ideal of Jesus and Mary. What an amazing achievement and incredibly smart marketing of ideas? This brings me to my final point - what Nazrul did by using the traditions of India as his source? He called for an elimination of strife between them. The words of his last speech are as relevant today as they were when he wrote them. They speak to me of a man who had the romantic notion that we all are of many, yet "one tradition", not only India, Pakistan and Bangladesh but across the world.

I would caution, however, that one must bear in mind the definition of development as Nazrul saw it, not as the latter phenomenon is commonly thought of or defined. With Nazrul;s definition, in our thinking, we find that he occupies a special place in thinking about the emancipation of women.

\section{End Notes}

${ }^{1}$ Langley, Winston E. (2007) Kazi Nazrul Islam The Voice of Poetry and the Struggle for Human Wholeness, Dhaka, Nazrul Institute, p.168.

2 Huda, Muhammad Nurul [ed.] (2000) Poetry of Kazi Nazrul Islam, Dhaka, Nazrul Institute, p.289.

${ }^{3}$ Ibid, p. 294.

${ }^{4}$ Ibid., p. 295.

${ }^{5}$ Ibid. p. 296. 
${ }^{6}$ Langley, op. cit., (2007), p.173.

7 op. cit., p.284.

\section{Bibliography}

Holland, Dorothy, et al. (1998) Identity and Agency in Cultural Worlds, Cambridge, Harvard University Press, p. 52.

Dr. Muhammad Abu Tayyub Khan is Assistant Professor in the Department of Bengali, University of Karachi. 